Historic, Archive Document

Do not assume content reflects current scientific knowledge, policies, or practices. 
) 


\section{The Birth of a New Industry}

New. Timber Trees for Both Beauty and Profit. The Most Rapid Growing and Most Valuable Hardwood Timber Trees Known

\section{The Hardwood Problem Solved}

THE TIME IS HERE now when a thrifty young "ROYAL"

1 grove will sell more readily and for a better price than the best prune or orange orchard, both of which need constant outlay, care and attention, while a "ROYAL" grove requires very little attention. Fruit trees or other crops can be grown among the Walnut trees, and poultry, sheep or hogs will even help them along.

The first "ROYAL" Walnut ever produced by the skill of man was produced on my own grounds and was first named, first described, and first introduced by myself. If you wish to start right it is well to go to the fountainhead by purchasing trees or nuts for a grove DIRECT FROM THE ORIGINATOR. It saves trouble later, as the originator of a new tree or plant or product of any kind must feel an interest in its success which is not often shared by others who have something to offer "just as good as BURBANK'S."

\section{LUTHER BURBANK}

BURBANK'S

EXPERIMENT FARMS
SANTA ROSA, CALIFORNIA, U.S. A. 


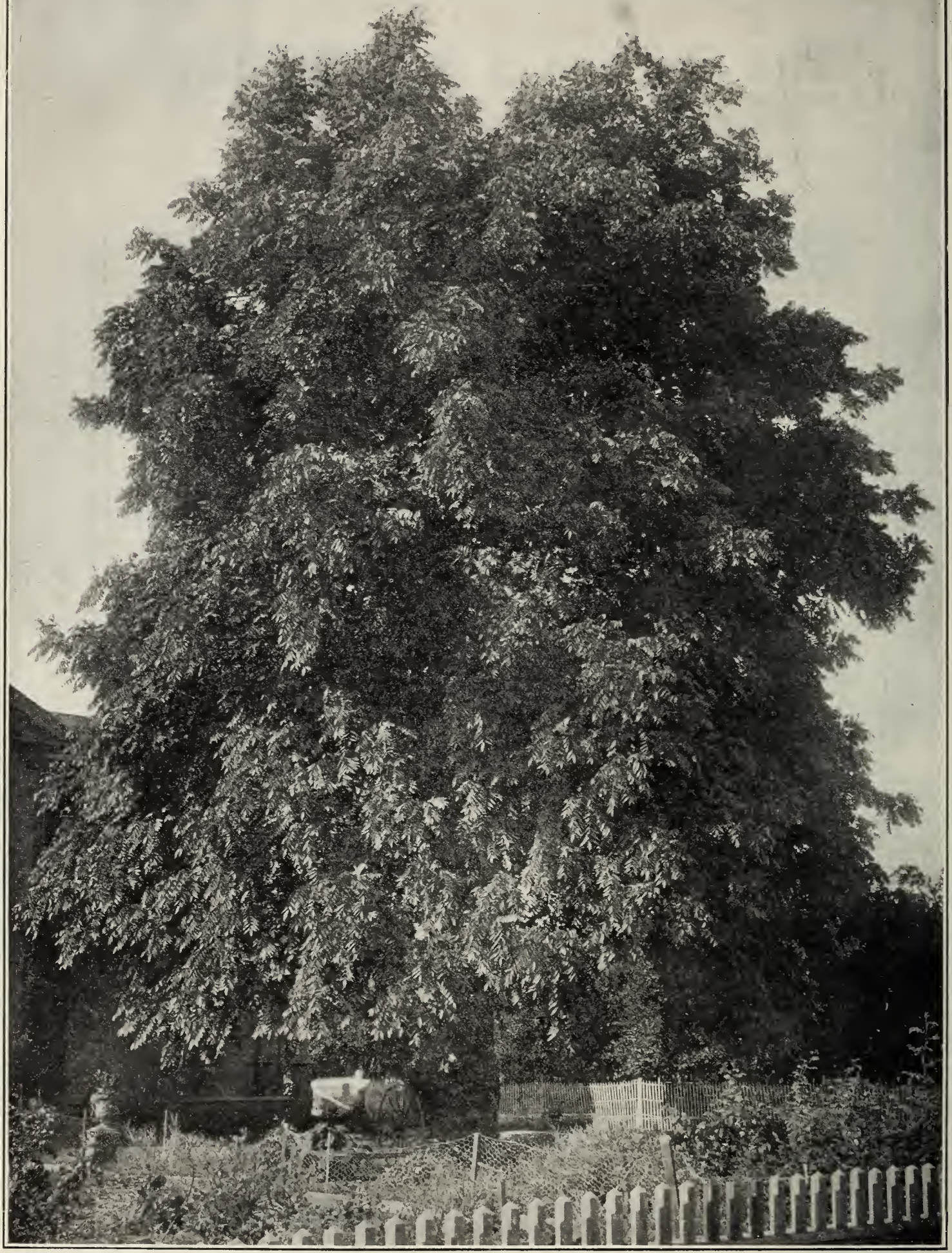

THE BURBANK ORIGINAL "ROYAL" WALNUT TREE.

Twenty-Four Years of Age; Ninety-Six Feet in Height With a Spread of Sixty-Six Feet of Branches and a Girth of Nine Feet Three Inches at Six Feet Above the Ground and the Same at Twelve Feet. 


\section{The Burbank ROYAL Walnut}

URING THE YEARS from 1878 to 1885 I was experimenting extensively with our native nut trees, the Black Walnut of the Eastern States (Juglans Nigra), our native Black Walnut (J. Californica), the Texas Black Walnut (J. Rupestris), and the Asian Walnuts (J. Manschurica), (J. Sieboldi) ; also the South American Black Walnut (J. Nigra var.), the Butternut (J. Cinerea), and a dozen or more other species and varieties.

The result of a cross of a rapid growing Eastern Black Walnut and our Northern California, handsome, rapid growing native Black Walnut, produced the variety now known everywhere as the "Royal," which will outgrow any other known walnut tree on earth, whether produced by Nature or by the skill of man. The "Royal" has come to be known not only as the best of all walnuts for timber production, but also from its unequaled vigor as a stock on which to graft all the best soft shell walnuts of commerce; it being found by general experience that trees grafted on the "Royal" root make a better growth, bear more and larger nuts of better quality, and are far less subject to the blight.

But above all, the value of the "Royal" is for timber, which it will produce at about one-eighth of the expense of the ordinary Black Walnut timber and in less than one-quarter of the time. Do these astounding results mean anything? A tree that will produce the most beautiful and most costly of all our American hardwoods with a speed almost or quite equaling the semi-tropical eucalyptus means simply that it is now a foolish waste of time and labor to plant timber groves of any other kind, especially when it is well known that old Black Walnut fences, stumps, and the inside finish of old houses are now eagerly sought for making walnut veneers, being too expensive to use solid as formerly, even before the whole American supply was exhausted.

The wood of the "Royal" often shows an annual growth of nearly one inch all around the tree each season, while the bark is thinner than that of the ordinary Black Walnut.

When I first announced this rapid growing walnut, most lumber men and those who had used the common Black Walnut in the manufacture of furniture and pianos were very doubtful; some of them even very sure that it would prove to be softer than the Eastern Black Walnut, which they were then using. Therefore, I cut a large branch from my original enormous trees and submitted pieces of the timber to several New York and Chicago piano and furniture makers, all of whom pronounced it heavier, harder, closer grained, and of a finer, silkier texture and in ALL RESPECTS SUPERIOR to the common Black Walnut. This could, of course, leave no doubt of its superior quality for every purpose for which Black Walnut is used.

This really wonderful new timber and surpassingly beautiful shade tree probably can not be profitably grown where the thermometer falls much lower than twenty or thirty degrees below zero, as with such a 
winter temperature the tips are frozen back occasionally, which checks the trees badly if too often repeated. The trees, however, live in Eastern Canada, and thrive with unexampled vigor on any deep alluvial soil throughout most of the United States.

The value of the "Roral" as a shade and ornamental tree with its grace, beauty, and towering proportions is well shown by the photograph of one of the original trees which now, at twenty-four years of age, is ninety-six feet in height with a spread of sixty-six feet of branches and a girth of nine feet three inches at six feet above the ground and the same at twelve feet. If any other nut tree of the same age, of equal size and beauty has ever been seen, it has never yet been mentioned. This "Royal" tree also produces an enormous quantity of large Black Walnuts, better in quality than any other Black Walnut.

The trees should be planted forty to fifty feet apart each way in groves for timber or they may be planted twenty to thirty feet apart and every other one removed before they begin to crowd.

While the trees are young, the ground may be used for various farm crops, fruit trees, chickens and other purposes, but on good soil the larger spaces will soon be covered.

These two yearling trees show the extremes in walnut growth. Both were grown side by side the same season on the same land with exactly the same treatment. The larger tree will produce wood and timber at least one hundred times as fast as the smaller one, not only when young, but ALWAYS. The tall one shown in the picture grew six feet one and one-half inches from the surface of the ground; the other only one inch. The roots, of course, as may be seen, were in proportion to the top growth.

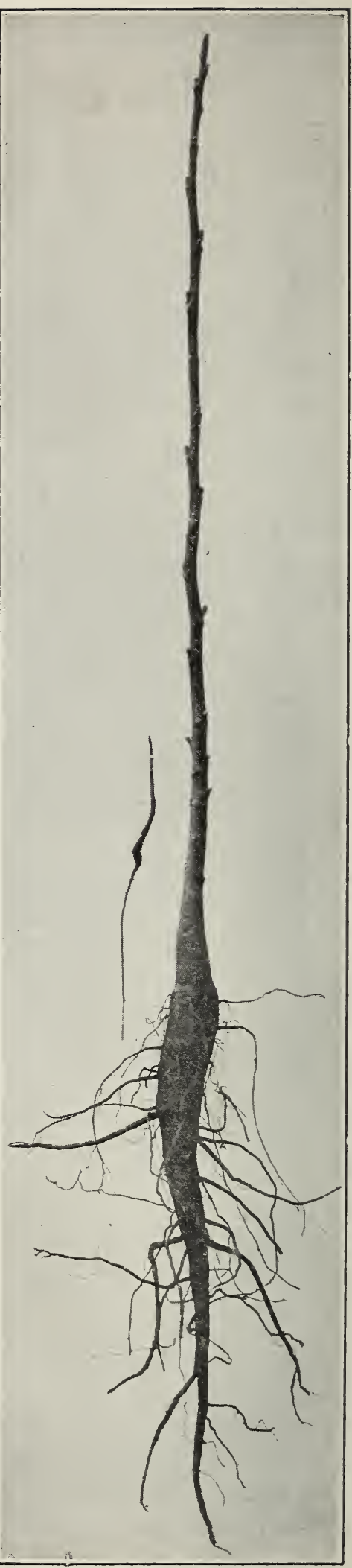




\section{Directions for Planting and Care}

When the trees are received see that the tap root is shortened by a clean sloping cut, leaving the root about twice as long as the top; plant same depth it grew in the nursery or a shade deeper; pack soil well about the roots. A slight shade of weeds or straw the first season is beneficial but not necessary. In dry climates a gallon or so of water once in July or August the first Summer will insure greater growth yet is not necessary, as the "Royals" are fully capable of caring for themselves.

The "Royal" nuts may be planted at any season two inches deep and five or six inches apart in the rows, which may be from one to four feet apart. All may be transplanted to permanent positions when one year old. For permanent groves about 40 to 50 feet apart is best, that is, 20 to 31 trees per acre; for street planting 50 to 60 feet apart is better. A well located twenty-year-old grove should be worth even at present prices some ten to sixteen thousand dollars per acre.

Let it be remembered that although the facts stated above are correct in every particular as nearly as it is possible to state facts, yet I do not recommend everybody to plant "Royals" for timber. Only those who can afford to wait for ten or twenty years, great as the profits will be, should invest in this most attractive enterprise, so well suited to those who have land on which this unusual investment will yield great returns with so little trouble and labor. But all may plant a few trees for beauty and the enhancement in value which grand trees bring to any piece of land, and even one $\$ 500$ or $\$ 600$ tree is worth having.

The largest and most frequent orders for the "Royal" Walnut come from the very States where the Black Walnut used to grow and where now a good old Black Walnut tree will sell at from $\$ 200$ to $\$ 800$, or if extra fine for $\$ 1000$ or more, and where good Black Walnut lumber brings as high as $\$ 200$ to $\$ 500$ per thousand feet. The "Royal" is especially adapted to reforesting, roadside planting, and for general shadetree purposes. In one case a request was received for ten million treesof the "Royal"- one million a year for ten years. As there are not enough of the "Royal" Walnuts in the world to supply such a request, it was, of course, reluctantly refused, though the original "Royal" tree always bears great crops of nuts. We have counted the crop this season and find there are 17,160 nuts and there are a few still on the tree, in all amounting to a little over forty-five bushels as they fall in the husk. The nuts are large and the meat is far superior to that of any other black walnut. 


\section{PRICES}

As our "Royal" WValnut trees are nearly all sold for the 1920-21 season, we can offer only a few trees:

Extra Selected one year trees of "RoyaL" from the Original tree; each $\$ 1.25$; ten, $\$ 8$.

One Year Selected as above; each, $80 \mathrm{c}$; ten, $\$ 6$.

Nuts for planting as follows:

10 nuts........\$ 1 postpaid

100 nuts........ 5 by express

1,000 nuts ...... 40 by express

\section{NEW PATAGONIA CHERRY}

Seeds received from the "Sociedad Explotadora de Terra del Fuego" from Rio Aysen, south of Chile, May, 1913, stating that they were "from a tree with very pretty flowers and yielding the tough wood used locally for cart axles."

This and the "Royal" Walnut are of equal value as timber trees. Extremely rapid growth; wood of beautiful color, close silky grain; harder than any other wood except Boxwood and Ironwood. Fruit also abundantly produced and valued; easily transplanted.

Two to three feet; each $60 \mathrm{c} ; 10, \$ 5 ; 100, \$ 40$.

One-year seedlings 6 to 12 inches; best size for forest planting; each, $30 \mathrm{c} ; 100, \$ 15 ; 1,000, \$ 100$.

\section{OTHER NEW AND STANDARD NURSERY STOCK}

APPLES-All two-year, extra fine, branched trees.

$\checkmark$ GOLDRIDGE: Best winter apple.

AUTUMN RUSSET: Medium size, fine quality. Crimson.

All apples, each, 75c; 10, $\$ 6 ; 100, \$ 50$.

PLUMS-All two-year branched trees.

BEAUTY : The best home and shipping plum known. Produces large, early, delicious fruit.

BEAUTY JUNIOR: Later; deep crimson; superior.

INCA: Very large, yellow, superior quality; very productive; a fine home or shipping plum.

CRIMSON CLUSTER: Latest of all; ripening in November; enormously productive, beautiful; superior.

PURPLE LEAF : New and beautiful; ornamental.

All plums, each, 90c; $10, \$ 8$.

AMERICAN ELM : Large, eight to twelve feet; each, $\$ 1.50 ; 10, \$ 12$.

SEEDLING MIRACLE CHESTNUTS: (Grafted trees all sold.) These vary in size and productiveness. Most of them bear immediately. Each, $50 \mathrm{c} ; 10, \$ 3 ; 100, \$ 25$.

EUREKA WALNUTS: (Selected seedlings.) Two to three feet. Each, $75 \mathrm{c} ; 10, \$ 6$. 
NEW WHITE FRENCH TUBEROUS ARTICHOKE: Produces more latent sugar per acre than any other known plant. Fine for stock and especially hog feed. Pound, 40c; 10 pounds, $\$ 2 ; 100$ pounds, $\$ 15$.

QUALITY ASPARAGUS: The most delicious of all. Large sweet, white stalks. Plant now. One-year roots; $10,50 \mathrm{c} ; 25, \$ 1 ; 100, \$ 2$.

Select two-year roots, $10, \$ 1 ; 25, \$ 2 ; 100, \$ 4$.

BONVALLET'S GIANT ASPARAGUS: Large and fine for market. One-year roots, $10,40 \mathrm{c} ; 25,65 \mathrm{c} ; 100$, $\$ 2.50$. Two-year roots, 10 , 60c; $25, \$ 1 ; 100, \$ 3$.

NEW GIANT RUST-PROOF ASPARAGUS: One-year roots, 10, 40c; $25,65 \mathrm{c} ; 100, \$ 2.50$. Two-year roots, $10,60 \mathrm{c} ; 25, \$ 1 ; 100, \$ 3$.

BURBANK'S GIANT PERPETUAL RHUBARB: The most desirable of all rhubarbs for mild climates and has often been called "The Mortgage Lifter" because of the great profit derived from it. Each, $60 \mathrm{c} ; 3, \$ 1.50$; $10, \$ 3$.

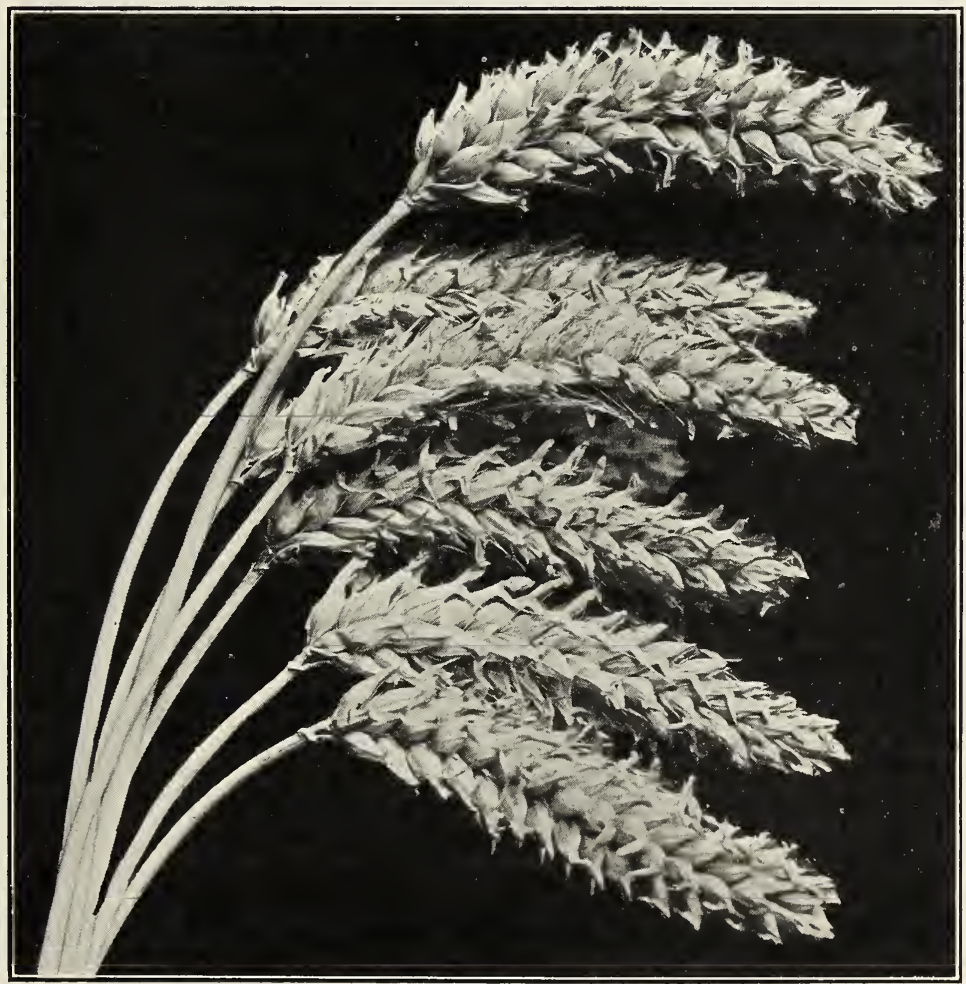

NEW BARLEY, THE PEARL.

\section{TWO REMARKABLE NEW GRAINS}

A NEW BEARDLESS HULL-LESS BARLEY : THE PEARL-The old well-known Nepaul beardless hull-less barley was the best for hay, yielding a large crop in the shortest time. The grain, however, was of all sizes, shapes and colors; very far from a perfect one. After a number of 
years of most rigid, careful selection, kernel by kernel, head by head, plant by plant, row by row, this new WHITE Beardless Hull-less productive barley was produced. It will produce a great crop of unusually large, white grain of superior weight and quality.

1 pound, by mail.................... 1

5 pounds, by mail.................... 3

10 pounds, by mail................... 5

25 pounds, by express................. 9

Per bushel (60 pounds), by express.......... 18

A NEW RYE "WHITE GIANT": There is no grain crop that has such a beneficial action on all soils as rye. There is no other grain that will thrive on the poorest of soils, improving them for all other crops instead of exhausting them. A crop of rye rejuvenates all soils. I now offer a rye which is a giant in growth and productiveness, and better still, the grain is very light colored, large and fat. It is the best and the most productive rye.

1 pound, by mail................... $\$ 1$

5 pounds, by mail.................... 3

10 pounds, by mail................... 5

25 pounds, by express................. 9

Per bushel (60 pounds), by express.......... 18

\section{BAMBUSA HENONIS (Phyllostachis henonis)}

The Bamboos are one of the most useful and ornamental plants which grow on the earth. Of these there are over two hundred species, some of which thrive from sea level up to 15,000 feet. They are cultivated not only for use in a hundred different ways, but also for their surpassing grace and beauty. Most of them are tropical or semitropical, but some are quite hardy, enduring a zero temperature. Many Bamboos bloom so seldom that it has even been impossible to classify them, and others bloom only once in a lifetime, bear seed, and die.

The United States Government has lately prohibited the further importation of bamboos on account of the danger of introducing insect pests. Fortunately an old hardy bamboo on my home place bloomed throughout the whole large clump last summer, produced seed and promptly died. From these seeds I have raised a lot of thrifty young bamboos of the zero type of hardiness. This species, while one of the most beautiful, graceful and hardy of all the bamboos, also furnishes a constant supply of light, strong plant stakes, bean poles, and fishing poles, while adding a unique grace and beauty wherever placed. These can be grown as house ornaments in the colder Eastern states, and planted out in the spring. Each, $75 \mathrm{c}$; three, $\$ 1.50$; ten, $\$ 4$.

\section{NEW GIANT CHIVES}

The common, well-known chives, a small onion-like plant, is hardy even in Alaska, and a small plot will supply a family throughout the year. The tops are used for flavoring soups, salads, etc. Their delicate onion flavor is prized by those who know them. The Giant Chive, which lately originated on my grounds, is a wonderful improvement on all those ever before grown. Single sets, each, 25c; five, $\$ 1$; ten, $\$ 1.50$. 